\title{
Interventions and decision-making at the end of life: the effect of establishing the terminal illness situation
}

\author{
C. Campos-Calderón ${ }^{1}$, R. Montoya-Juárez ${ }^{2 *}$, C. Hueso-Montoro², E. Hernández-López ${ }^{3}$, F. Ojeda-Virto ${ }^{4}$ \\ and M. P. García-Caro ${ }^{2}$
}

\begin{abstract}
Background: Many 'routine' interventions performed in hospital rooms have repercussions for the comfort of the patient, and the decision to perform them should depend on whether the patient is identified as in a terminal phase. The aim of this study is to analyse the health interventions performed and decisions made in the last days of life in patients with advanced oncological and non-oncological illness to ascertain whether identifying the patient's terminal illness situation has any effect on these decisions.
\end{abstract}

Methods: Retrospective study of the clinical histories of deceased patients in four hospitals in Granada (Spain) in 2010. Clinical histories corresponding to the last three months of the patient's life were reviewed.

Results: A total of 202 clinical histories were reviewed, $60 \%$ of which were those of non-oncology patients. Opioid prescriptions (58.4\%), palliative sedation (35.1\%) and Do Not Resuscitate (DNR) orders (34.7\%) were the decisions most often reflected in the histories, and differences in these decisions were found between patients registered as terminal and those who were not registered as terminal. The most frequent interventions in the final 14 days and $48 \mathrm{~h}$ were parenteral hydration (96-83\%), peripheral venous catheter (90.1-82 \%) and oxygen therapy (81.2-70. $5 \%)$. There were statistically significant differences between the patients who were registered as terminal and those not registered as terminal in the number of interventions applied in the final 14 days and $48 \mathrm{~h}(p=0.01-p=0.00)$ and in many of the described treatments.

Conclusion: The recognition of a patient's terminal status in the clinical history conditions the decisions that are made and is generally associated with a lower number of interventions.

Keywords: Decision making, Delivery of care, End-of-life care, Hospital care, Prognosis, Symptom management

\section{Background}

The experience of a patient at end of life is marked not only by the symptoms suffered, but also by other factors, such as the actions and decisions regarding treatment taken by the professionals attending the patient $[1,2]$. From a palliative point of view, in the final days, one must consider a decision-making method that has patient comfort as its primary objective and that manages the efficacy and provision of treatments according to this standard.

\footnotetext{
* Correspondence: rmontoya@ugr.es

${ }^{2}$ Nursing Department, University of Granada, Granada, Spain

Full list of author information is available at the end of the article
For physicians, the identification of a patient's terminal status should represent an inflection point to reflect upon which measures to undertake or not, with the goal of avoiding unnecessary suffering for the patient. However, studies related to end-of-life decisions show the difficulties doctors encounter in recognizing a patient's proximity to death and/or in noting this proximity in their reports [3-6]. The motives for this difficulty appear to be related to fear of making a mistake [7], the emotional 'weight' of the terminal diagnosis $[8,9]$, and an optimistic attitude regarding the patient's prognosis $[10,11]$. In this same vein, some studies confirm that even in obviously advanced conditions, patients were exposed to life-sustaining interventions and practices, such as mechanical ventilation, transfusions, 
parenteral nutrition, extrarenal purification, etc., until the end of life [12, 13].

Scientific literature informs the big decisions that direct a more intrusive or a more palliative treatment in a terminal clinical situation. When speaking of end-of-life decision-making, these appear to be centred basically in crucial measures associated with medical aspects, such as sedation, withdrawal of medication, refusal of admission to the intensive care unit (ICU), the omission or withdrawal of antibiotics, hydration, or the use of mechanical ventilation $[14,16]$. Similarly, the majority of the studies conducted relate to patients who have died in specialized ICUs [17-19].

However, in a context like the Spanish one, in which the majority of patients in advanced and terminal states are attended in hospital units in the weeks preceding their death, decisions regarding the patient's comfort relate to interventions that are considered routine.

Interventions such as the insertion of urinary and intravenous catheters, the use of aspirators and other actions that are common for patient care in general hospital units have not been considered in the literature on decision-making in this type of context [20, 21], yet these daily decisions can make the difference between comfort and discomfort for these patients. The recommended best clinical practice for these patients entails limiting the use of actions that will not reduce their suffering and allowing the unrestricted use of interventions that can provide relief, such as providing opioids for pain management and dyspnoea [22-25].

Taking these considerations into account, a descriptive study was designed to review clinical histories to determine the relevant health interventions and decisions performed in the final days of life in hospital rooms. Similarly, the study aimed to determine whether the registration of the patient's terminal status had any effect on these actions/decisions. Specifically, the objectives of the present study were as follows:

1) To describe the decisions made in the final three months of patients' lives and the interventions applied 14 days and $48 \mathrm{~h}$ before death.

2) To analyse these decisions andcompare the findings for patients registered as being in the terminal stage of illness with those for patients who were not registered as terminal.

3) To compare the decisions made and interventions provided during the final 14 days and $48 \mathrm{~h}$ of life in terms of the moment at which the terminal phase was registered.

\section{Methods}

A retrospective study was performed, evaluating the clinical histories of patients who died between January 1 and December 1, 2010 in various public hospitals in the province of Granada (Spain). The study was approved by the ethics committee of each hospital.

\section{Selection of clinical histories/sample}

To calculate the sample size, a total population of 4031 deaths in hospitals and primary care settings was assumed. For a $5 \%$ precision in estimating the proportion using a confidence interval with a normal asymptote with correction for finite populations at $95 \%$ bilaterally, the estimated sample was 252 clinical histories.

Clinical histories were included for patients whose causes of death, as recorded in the death records of the hospitals' documentation services, were ICD-9 diagnostic codes related to advanced oncological and nononcological diseases Table 1.

The clinical histories were selected through the centres and were proportional to the number of patients who died in each centre. Deaths that occurred within $24 \mathrm{~h}$ following hospital admission were excluded. We also excluded 50 clinical histories of patients who died at home after receiving care from primary care teams because of differences in the format and type of data registered by those teams compared with the data registered by hospitals.

\section{Procedure}

For the selection and identification of clinical histories, the clinical documentation services of each hospital were contacted. Additionally, data for the year 2010 were solicited from the death registries of each hospital where the basic cause of death included any of the aforementioned diseases Table 1.

The clinical histories were selected and reviewed during the year 2011. The documents reviewed in the clinical histories were the registration report and the medical and nursing charts from the last 3 months of the patients' lives.

Three investigators performed the data collection. To ensure the quality of the data collection and to ascertain agreement in the valuation, a trial was conducted with 12 clinical histories in which certain items that were not easily calibrated were purged and others whose interpretations were unclear were redefined.

Socio-demographic variables were collected, as were clinical data on the diseases. The study variables were the notes in the clinical histories that allowed the identification of the patient's terminal situation, which was understood as an advanced illness in an evolved and irreversible state with multiple symptoms, emotional impact, loss of autonomy, little to no response to specific treatments and a prognosis of death within weeks or months within a context of progressive frailty [26]. We accepted all annotations that included explicit 
Table 1 Data collection protocol

\begin{tabular}{|c|c|}
\hline \multicolumn{2}{|l|}{ Sex } \\
\hline \multicolumn{2}{|l|}{ Age } \\
\hline Cause of death & $\begin{array}{l}\text { ICD-9 diagnostics dispatched in } \\
\text { the death records of the } \\
\text { documentation services of the } \\
\text { hospitals included in the study. } \\
\text { Oncological disease: } 140-195 ; \\
\text { 196-198; 199; 200-208 } \\
\text { Cardiac insufficiency: 402.0.1; 402.11; } \\
\text { 402.91, 404; 428; 428.1 } \\
\text { Hepatic insufficiency: 571; } 572 \\
\text { Respiratory insufficiency/COPD: } \\
\text { 491.21; } 518.84 \\
\text { Chronic renal insufficiency: } 585\end{array}$ \\
\hline Date of death & $\begin{array}{l}\text { Dispatched in the death records } \\
\text { of the documentation services of } \\
\text { the hospitals included in the study }\end{array}$ \\
\hline $\begin{array}{l}\text { Time elapsed since patient was } \\
\text { diagnosed }\end{array}$ & $\begin{array}{l}\text { Noted in the patients' clinical } \\
\text { histories } \\
>1 \text { year } \\
\leq 1 \text { year }\end{array}$ \\
\hline $\begin{array}{l}\text { Comorbidity according to the } \\
\text { Charlson index }\end{array}$ & $\begin{array}{l}\text { Individually calculated for each } \\
\text { patient as a function of the diverse } \\
\text { pathologies noted in the clinical } \\
\text { histories. }\end{array}$ \\
\hline $\begin{array}{l}\text { Hospital department where } \\
\text { patient died }\end{array}$ & $\begin{array}{l}\text { Dispatched in the death records of } \\
\text { the documentation services of the } \\
\text { hospitals included in the study }\end{array}$ \\
\hline Hospitalisation & $\begin{array}{l}\text { Number of hospital admissions, } \\
\text { final three months of life } \\
\text { Number of days of the final } \\
\text { hospital admission }\end{array}$ \\
\hline
\end{tabular}

Medical end-of-life decisions in the final 3 months of life

Notation of the decision marked - Continuation of care in home in the clinical history and date at - Consult or referral to palliative care which it first appears.

Categorical dichotomy response: Yes-Not noted

Affirmative response: Date

- Withdrawal or non-issuance of a determined treatment/intervention.

- Decision of withholding/ withdrawing interventions

- Not running diagnostics tests

- Withdrawal of medication

- Withdrawal or non-issuance of antibiotic

- Rejection of ICU consult or rejection of ICU ingress

- Initiation of opioid medication

- Initiation of sedation

- Do Not Resuscitate order

Interventions performed in the final 14 days and $48 \mathrm{~h}$

$\begin{array}{ll}\text { These interventions were } & \text { - Urinary catheter } \\ \text { performed at least once in the } & \text { - Central venous catheter } \\ \text { final } 14 \text { days and } 48 \mathrm{~h} \text { of the } & \text { - Peripheral venous catheter } \\ \text { patient's life. } & \text { - Nasogastric tube } \\ \text { Categorical dichotomy response: } & \text { - Enteral nutrition } \\ & \text { - Parenteral nutrition } \\ \text { Yes-Not noted. } & \text { - Invasive mechanical ventilation } \\ & \text { - Non-invasive mechanical } \\ & \text { ventilation } \\ & \text { - Transfusion } \\ & \text { - Aspirator } \\ & \text { - Aerosols } \\ & \text { - Oxygen therapy }\end{array}$

Table 1 Data collection protocol (Continued)

$$
\begin{aligned}
& \text { - Antibiotics } \\
& \text { - Drainage } \\
& \text { - ICU consult } \\
& \text { - ICU ingress }
\end{aligned}
$$

Identification of the clinical terminal situation in the final three months of life

Identification of the terminal Express notation of terminality noted situation of the patient and the in the clinical histories and date at moment at which this situation is which the notation is first produced. produced. Other expression(s) used by

Categorical dichotomy response: clinicians to refer to terminality, such Yes-Not noted

Affirmative response: Date and date first produced.

expressions related to this situation, such as 'terminal', 'agony', 'bad prognosis', and 'palliative'. Meanwhile, the interventions that the patient received in the final days of life were concretely collected for two time periods: 14 days and $48 \mathrm{~h}$ before death. In addition, socio-demographic variables were collected, as were clinical data regarding the diseases.

\section{Instrument}

A data collection protocol was designed that included the aforementioned variables. This document was agreed upon by the investigative group of a broader project called 'Variability of Clinical Practice and Conditional Factors in the Implementation of the Processes of Attention at End of Life,' in which the present work is included Table 1.

\section{Data analysis}

A descriptive analysis of the principle variables studied was conducted. For the quantitative variables, the means, medians, and standard deviations were calculated. The qualitative variables are expressed using absolute and relative frequencies. To represent the data, frequency tables and figures are used.

To ascertain the existence of significant differences among the groups formed using the variables studied (i.e., patients who were registered as being in the terminal stage of illness versus patients who were not registered as such), Student's T-test was used for independent samples, and the Pearson chi-squared test or Fisher's exact test were used as appropriate for the qualitative variables. For all of the contrasts, a significance level of $p \leq 0.05$ was considered.

\section{Results}

\section{Description of the sample}

The sample consisted of a total of 202 clinical histories that met the inclusion criteria. The characteristics of the patients' deaths are shown in Table 2. Regarding the cause of death, $60 \%(n=121)$ of the clinical histories 
Table 2 Characteristics of the patients who were registered as terminal and those who were not

\begin{tabular}{|c|c|c|c|c|c|c|c|}
\hline \multirow[t]{2}{*}{ Variables } & \multirow{2}{*}{$\begin{array}{l}\text { Total } \\
N=202\end{array}$} & & \multicolumn{2}{|c|}{ Registered terminal situation } & \multicolumn{2}{|c|}{$\underline{\text { Registered terminal situation }}$} & \multirow[t]{2}{*}{$p$} \\
\hline & & & $\begin{array}{l}\text { Yes } \\
N=104\end{array}$ & & $\begin{array}{l}\mathrm{No} \\
N=98\end{array}$ & & \\
\hline \multirow[t]{2}{*}{ Age } & 72.81 years & & 72.13 years & & 73.56 years & & 0.470 \\
\hline & $(\mathrm{SD}=13.85)$ & & $(S D=14.69)$ & & $(\mathrm{SD}=12.91)$ & & \\
\hline \multirow[t]{2}{*}{ Sex } & Male & Female & Male & Female & Male & Female & 0.865 \\
\hline & $\begin{array}{l}58.5 \% \\
(n=108)\end{array}$ & $\begin{array}{l}46.5 \% \\
(n=94)\end{array}$ & $\begin{array}{l}52.9 \% \\
(n=55)\end{array}$ & $\begin{array}{l}47.1 \% \\
(n=49)\end{array}$ & $\begin{array}{l}54.1 \% \\
(n=53)\end{array}$ & $\begin{array}{l}45.9 \% \\
(n=45)\end{array}$ & \\
\hline \multirow[t]{2}{*}{ Pathology } & Oncological & Not oncological & Oncological & Not oncological & Oncological & Not oncological & 0.003 \\
\hline & $\begin{array}{l}40.1 \% \\
(n=81)\end{array}$ & $\begin{array}{l}59.9 \% \\
(n=121)\end{array}$ & $\begin{array}{l}50 \% \\
(n=52)\end{array}$ & $\begin{array}{l}50 \% \\
(n=52)\end{array}$ & $\begin{array}{l}29.6 \% \\
(n=29)\end{array}$ & $\begin{array}{l}70.4 \% \\
(n=69)\end{array}$ & \\
\hline \multirow{2}{*}{$\begin{array}{l}\text { Time elapsed since patient } \\
\text { was diagnosed }\end{array}$} & $<1$ year & $>1$ year & $<1$ year & $>1$ year & $<1$ year & $>1$ year & 0.327 \\
\hline & $\begin{array}{l}29.7 \% \\
(n=46)\end{array}$ & $\begin{array}{l}70.3 \% \\
(n=109)\end{array}$ & $\begin{array}{l}32.9 \% \\
(n=28)\end{array}$ & $\begin{array}{l}67.1 \% \\
(n=57)\end{array}$ & $\begin{array}{l}25.7 \% \\
(n=18)\end{array}$ & $\begin{array}{l}74.3 \% \\
(n=52)\end{array}$ & \\
\hline \multirow[t]{2}{*}{ Comorbidity } & Low comorbidity & High comorbidity & Low comorbidity & High comorbidity & Low comorbidity & High comorbidity & 0.626 \\
\hline & $13.2 \%(n=22)$ & $86.8 \%(n=145)$ & $14.5 \%(n=12)$ & $85.5 \%(n=71)$ & $11.9 \%(n=10)$ & $88.1 \%(n=74)$ & \\
\hline
\end{tabular}

$p \leq 0.05$

were those of non-oncological patients; of these, $22 \%$ $(n=45)$ were cardiac insufficiency, $20 \%(n=40)$ were respiratory insufficiency/chronic pulmonary obstructive disease (COPD), $11 \%(n=22)$ were hepatic insufficiency and $7 \%(n=14)$ were chronic renal insufficiency. The rest of the clinical histories were of oncological patients (40\%, $n=81)$.

Regarding the hospitalization of the patients, $2 \%(n=4)$ of patients were hospitalized at three months, $50.5 \%$ at 14 days $(n=102)$, and $100 \%(n=202)$ at $48 \mathrm{~h}$ before death. During the last three months of life, $70 \%$ of patients had one hospital admission, $22.8 \%$ were admitted on two occasions, and $6.4 \%$ were admitted on three occasions. On average, the patients stayed in hospital 13 days (interquartile range 17-22) during their final admission, during which they died.

\section{Medical end-of-life decisions registered in the clinical histories}

Figure 1 shows the number and the total percentage of clinical histories in which the decision was explicitly recorded, along with the average number of days until the moment of death.

The prescription of opioids was the decision most frequently recorded in the clinical histories, with $58.4 \%(n=118)$, followed by palliative sedation with $35.1 \%(n=71)$ and Do Not Resuscitate (DNR) orders with $34.7 \%(n=70)$.

Decisions that were made earlier included the omission or withdrawal of dialysis, with a median of 15 days $(\mathrm{SD}=19.84)$; referral to the palliative care unit, with a median of 10.50 days $(\mathrm{SD}=22.91)$; and transfer to palliative care, with a median of 10 days $(S D=19.65)$.
Decisions that were made later, at a median of 1 day, were palliative sedation $(\mathrm{SD}=6.35)$, withdrawal of medication $(\mathrm{SD}=4.46)$ and refusal of ICU admission $(\mathrm{SD}=9.01)$.

\section{Interventions provided during the final 14 days and $48 \mathrm{~h}$ of life}

The interventions documented in the clinical histories in the final 14 days and $48 \mathrm{~h}$ of life are shown in Fig. 2.

The most frequently recorded interventions in the final 14 days and $48 \mathrm{~h}$ of life, respectively, were parenteral hydration, with $96 \%(n=194)$ and $83 \%(n=166)$; a peripheral venous catheter, with $90.1 \%(n=182)$ and $82 \%(n=164)$; and oxygen, with $81.2 \%(n=164)$ and $70.5 \%(n=141)$.

\section{Registry of the terminal situation in the clinical histories} In $51.5 \% \quad(n=104)$ of the clinical histories, some language that identified the patient as being in a terminal phase was observed. The median duration between the registration of the patient as terminal and the date of death was 5 days (min 1-max 90). Some $68.27 \%(n=71)$ of these terminal patients were registered before the $48 \mathrm{~h}$ immediately preceding their deaths, and the other $31.73 \%(n=33)$ were identified as terminal in the final $48 \mathrm{~h}$.

The group of patients registered as terminal showed characteristics that were similar to the patients who were not registered except for the type of disease, in which significant differences were present between oncology patients and non-oncology patients $(p=0.003)$. 


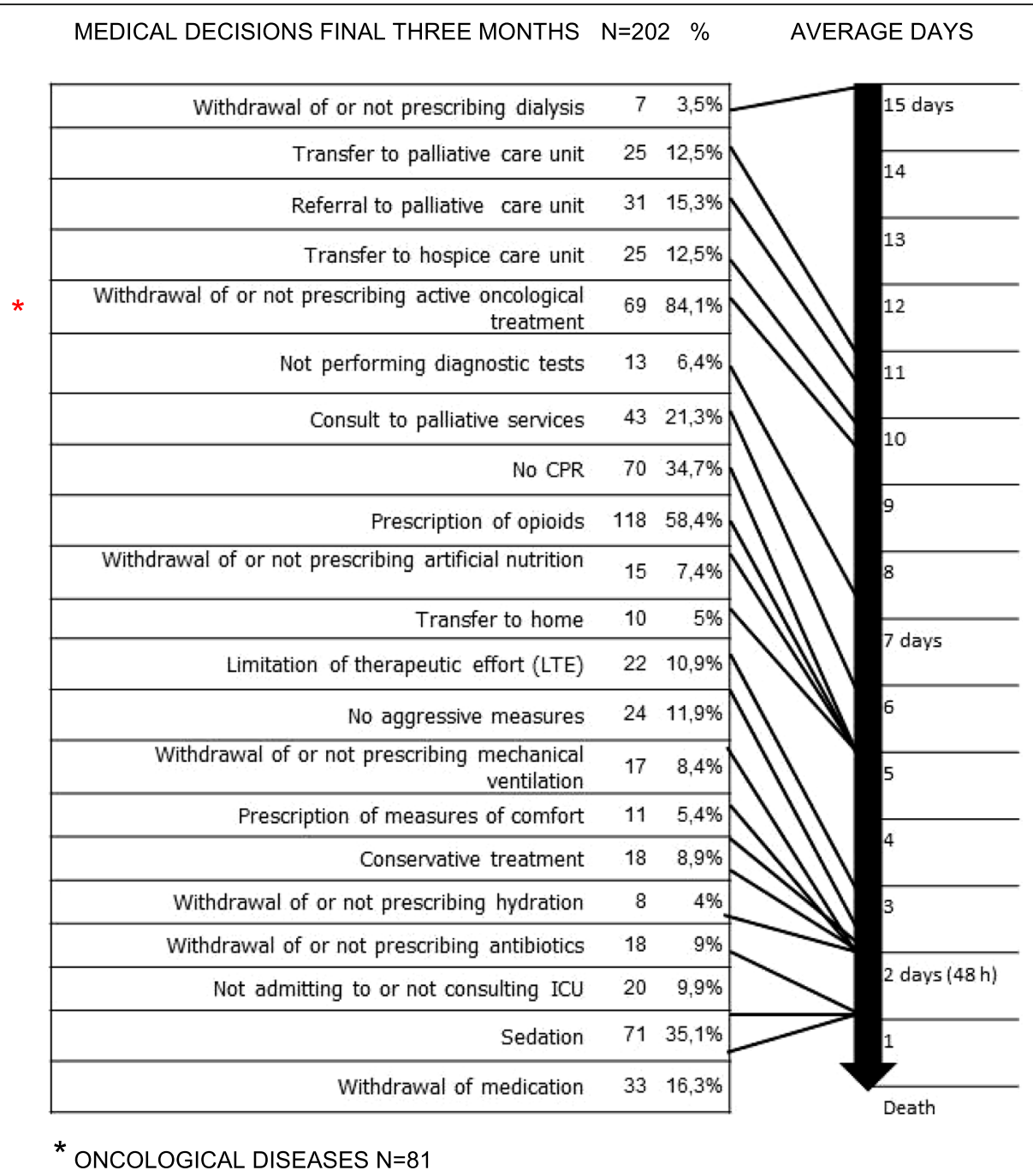

Fig. 1 Medical end-of-life decisions registered in clinical histories. * Oncological diseases N=81

Comparison of the decisions related to end-of-life care in patients who were and were not registered as in terminal illness situation

Table 3 shows the frequency of decisions related to endof-life that were made in the last 14 days of life and were registered in the clinical histories of the patients registered as terminal and those who were not. Significant differences were observed between the two groups regarding decisions to discontinue medications $(p=0.000)$ and to provide DNR orders $(p=0.002)$, palliative sedation $(p=0.011)$ and opioids $(p=0.002)$.

Similarly, the frequency of decisions registered in the clinical histories related to end-of-life care was analysed for the last $48 \mathrm{~h}$ of life for the patients registered as terminal and those who were not. Comparisons were made between decisions to provide palliative sedation, to prescribe opioids, and to discontinue medication; only the decision to discontinue medication showed significant differences $(p=0.002)$.

Regarding the time points at which decisions were registered in the clinical histories, medical decisions registered in the last $48 \mathrm{~h}$ of life were compared for the patients who were registered as terminal before their final $48 \mathrm{~h}(n=71)$ and those who were registered later $(n=33)$. Considering palliative sedation, opioid prescription, and the discontinuation of medication, significant differences were only found for opioid prescriptions $(p=0.023)$.

\section{Comparison of the interventions performed for patients registered as terminal and those who were not}

For the patients who were registered as terminal $(n=104)$, the average number of interventions in the final 14 days was six (min 0-max 22), and the average in the final $48 \mathrm{~h}$ 


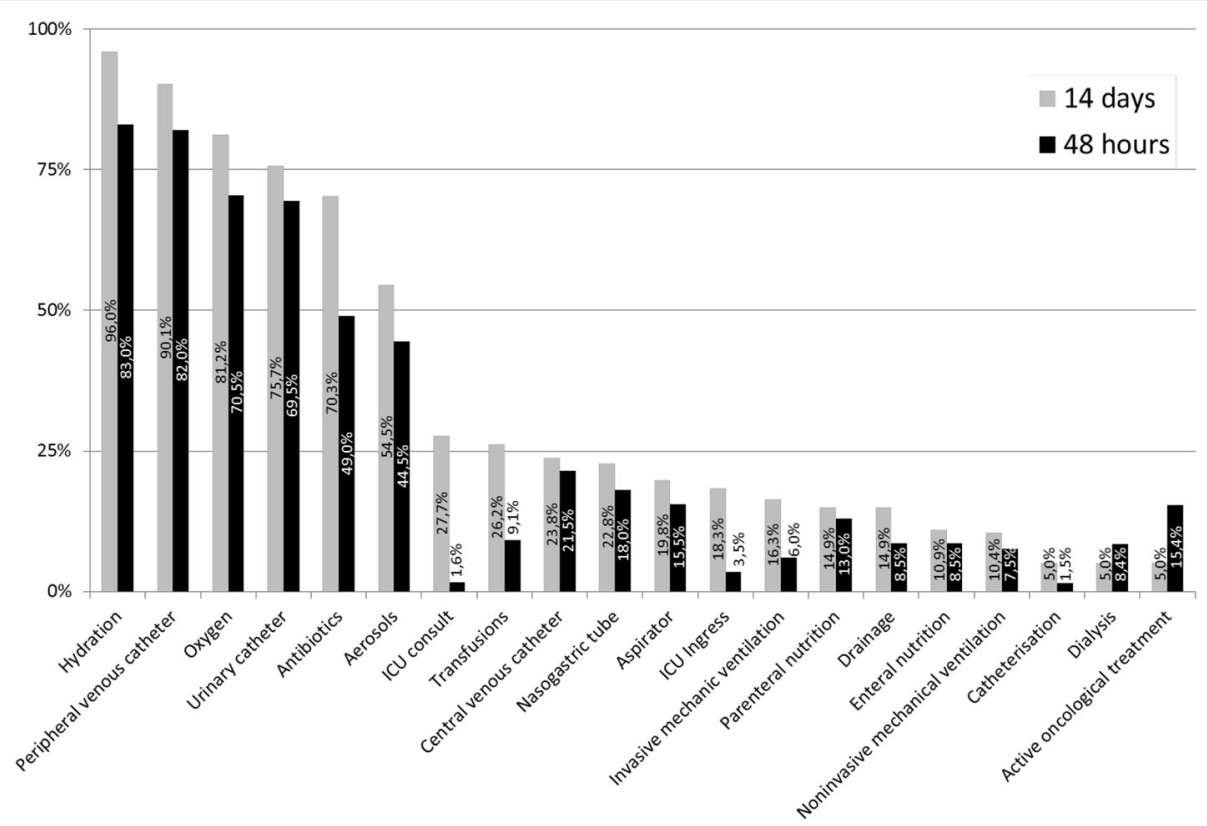

Fig. 2 Interventions performed in the final 14 days and $48 \mathrm{~h}$

was five (min 0-max 14). For the patients who were not registered as terminal $(n=98)$, the average was seven interventions ( $\min 3-\max 21)$ in the final 14 days and six interventions ( $\min 1-\max 14$ ) in the final $48 \mathrm{~h}$.

When comparing the number of interventions performed in the final 14 days and $48 \mathrm{~h}$ of life between the patients registered as terminal and those who were not, independent of the time point at which this registration was made, we found statistically significant differences for both the final 14 days $(p=0.010)$ and the final $48 \mathrm{~h}$ $(p=0.001)$.

The frequencies of the interventions performed in the final 14 days and $48 \mathrm{~h}$ of life for the patients registered as terminal and those who were not and a comparison between the two groups are outlined in Table 4.

Of the total number of patients registered as terminal $(n=104), 68.3 \%(n=71)$ were registered before the final $48 \mathrm{~h}$ of life and the rest, $31.7 \%(n=33)$, were registered during the final $48 \mathrm{~h}$. The patients registered as terminal before their final $48 \mathrm{~h}(n=71)$ underwent an average of four interventions in their final $48 \mathrm{~h}$, while those who were registered as terminal during their final $48 \mathrm{~h}(n=33)$ received an average of six interventions; the difference between the groups is significant $(p=0.002)$. Regarding the differences in the frequency of various interventions between the groups, significant differences were only found for the application of aerosols $(p=0.009)$. In Table 5, the frequency of interventions for both groups is shown.

\section{Discussion}

The objective of the present study was to analyse the interventions provided and decisions made in the final days of life and to determine whether registering the patient's terminal status had an effect on the implementation of these measures. The results appear to show that in the final days of the patient's life, there is intense therapeutic activity, and this activity is affected by the registration of the terminal phase of the disease in the patient's clinical history.

In the clinical histories, a great number of 'routine' procedures, including parenteral hydration, antibiotics, oxygen, insertion of peripheral venous catheters and urinary catheters, are documented in the final days of the patient's life. In this sense, our results are consistent with those of other studies centred on patients who died in hospitals during acute disease treatment, in which a greater intensity of interventions were registered at the ends of the patients' lives [27-29].

Approximately half of the clinical histories include some term that identifies the patient as being in a terminal state, and very few of these clinical histories register this information early. This generalized delay is demonstrated in a considerable number of publications [30, 31].

The identification of the terminal status is related to the decrease in the total number of interventions in the final days of life of the patient. In this sense, the study of Hui et al. [13] shows that the early establishment of the situation of terminal disease in patients with cancer is 
Table 3 End-of-life medical decisions made in the final 14 days and $48 \mathrm{~h}$ of life for patients who were registered as terminal and those who were not

\begin{tabular}{|c|c|c|c|c|}
\hline \multirow[t]{4}{*}{ Medical decisions related to end-of-life care } & \multicolumn{2}{|c|}{ Decisions in the final 14 days } & \multicolumn{2}{|c|}{ Decisions in the final $48 \mathrm{~h}$} \\
\hline & $\begin{array}{l}\text { Registered terminal } \\
\text { situation } \\
\text { Yes }\end{array}$ & $\begin{array}{l}\text { Registered terminal } \\
\text { situation } \\
\text { No }\end{array}$ & $\begin{array}{l}\text { Registered terminal } \\
\text { situation } \\
\text { Yes }\end{array}$ & $\begin{array}{l}\text { Registered terminal } \\
\text { situation } \\
\text { No }\end{array}$ \\
\hline & $n=104$ & $n=98$ & $n=104$ & $n=98$ \\
\hline & n (\%) & n (\%) & n (\%) & n (\%) \\
\hline Transfer to home & $5(4.8 \%)$ & $3(3.1 \%)$ & $2(1.9 \%)$ & $0(0 \%)$ \\
\hline Transfer to a care home & $5(4.8 \%)$ & $8(8.2 \%)$ & $0(0 \%)$ & $1(1 \%)$ \\
\hline Palliative consult & $14(13.5 \%)$ & $8(8.2 \%)$ & $3(2.9 \%)$ & $1(1 \%)$ \\
\hline Referral to palliative care unit & $8(7.7 \%)$ & $6(6.1 \%)$ & $1(1 \%)$ & $1(1 \%)$ \\
\hline Transfer to palliative care unit & $9(8.7 \%)$ & $4(4.1 \%)$ & $0(0 \%)$ & $0(0 \%)$ \\
\hline Decision of withholding/withdrawing interventions. & $12(11.5 \%)$ & $5(5.1 \%)$ & $5(4.8 \%)$ & $3(3.1 \%)$ \\
\hline Withdrawal of or not starting artificial nutrition & $4(3.8 \%)$ & $1(1 \%)$ & $2(1.9 \%)$ & $0(0 \%)$ \\
\hline $\begin{array}{l}\text { Withdrawal of or not prescribing parenteral } \\
\text { hydration }\end{array}$ & $5(4.8 \%)$ & $0(0 \%)$ & $3(2.9 \%)$ & $0(0 \%)$ \\
\hline $\begin{array}{l}\text { Withdrawal of or not starting mechanical } \\
\text { ventilation }\end{array}$ & $6(5.8 \%)$ & $6(6.1 \%)$ & $5(4.8 \%)$ & $5(5.1 \%)$ \\
\hline Withdrawal or non-prescription of antibiotics & $12(11.5 \%)$ & $1(1 \%)$ & $9(8.7 \%)$ & $1(1 \%)$ \\
\hline Not running diagnostic tests & $7(6.7 \%)$ & $0(0 \%)$ & $1(1 \%)$ & $0(0 \%)$ \\
\hline Withdrawal of medication & $29(27.9 \%)$ & $5(5.1 \%)$ & $20(19.2 \%)$ & $5(5.1 \%)$ \\
\hline Not entering into or consulting ICU & $6(5.8 \%)$ & $5(5.1 \%)$ & $4(3.8 \%)$ & $4(4.1 \%)$ \\
\hline Do Not Resuscitate order (DNR) & $36(34.6 \%)$ & $15(15.3 \%)$ & $9(8.7 \%)$ & $7(7.1 \%)$ \\
\hline Prescription of palliative sedation & $38(36.5 \%)$ & $20(20.4 \%)$ & $28(26.9 \%)$ & $15(15.3 \%)$ \\
\hline Prescription of opioids & $57(54.8 \%)$ & $32(32.7 \%)$ & $21(20.2 \%)$ & $15(15.3 \%)$ \\
\hline No aggressive measures & $3(2.9 \%)$ & $1(1 \%)$ & $2(1.9 \%)$ & $0(0 \%)$ \\
\hline Prescription of comforting measures & $14(13.5 \%)$ & $7(7.1 \%)$ & $8(7.7 \%)$ & $4(4.1 \%)$ \\
\hline Conservative treatment & $3(2.9 \%)$ & $1(1.0 \%)$ & $2(1.9 \%)$ & $0(0 \%)$ \\
\hline $\begin{array}{l}\text { Withdrawal of or not prescribing active } \\
\text { oncological treatment (oncology patients } n=81 \text { ) }\end{array}$ & $3(5.8 \%)$ & $1(3.4 \%)$ & $2(1.9 \%)$ & $0(0 \%)$ \\
\hline Withdrawal of or not prescribing dialysis & $2(1.9 \%)$ & $0(0 \%)$ & $0(0 \%)$ & $0(0 \%)$ \\
\hline
\end{tabular}

associated with changes in clinical practice, along with improvements in the quality of care.

According to the results of this study, despite the low frequency of some interventions, we can note that there is not much difference in implementation of interventions such as urinary or nasogastric intubation or central or peripheral intravenous catheterisation between patients who are registered as terminal and those who are not. These results concur with other studies, revealing that even in manifestly terminal conditions, patients were submitted to aggressive measures and important delays in the establishment of palliative objectives [12, 32]. All the same, it is necessary to perform a study with more participants to further support these conclusions.

Measures such as oxygen therapy or hydration deserve special mention, as they can be a clear indication of symptom control. There has been much controversy over hydration and its usefulness at the end of life; however, there is currently sufficient evidence to affirm that hydration does not have positive effects on the patient's quality of life, nor does it prolong survival [14, 33-36].

Regarding decisions associated with the end of life, we observed that the prescription of opioids and palliative sedation and DNR orders were the most frequently noted.

DNR orders appeared in an important number of clinical histories, both for patients who were registered as being in a terminal illness situation and those who were not. Nonetheless, the proportion found in the present study was lower than in other studies and was documented later in the patient's illness [13, 27, 37, 38]. Carrion's [39] study found that a DNR order has an effect on the plan of care; the variations found after signing a DNR order included the withdrawal of treatments 
Table 4 Comparison of the interventions performed in the final 14 days and $48 \mathrm{~h}$ in patients registered and not registered in a terminal situation

\begin{tabular}{|c|c|c|c|c|c|c|}
\hline \multirow[t]{5}{*}{ Interventions } & \multicolumn{3}{|c|}{ Interventions in the final 14 days } & \multicolumn{3}{|c|}{ Interventions in the final $48 \mathrm{~h}$} \\
\hline & \multicolumn{3}{|c|}{ Registered terminal situation } & \multicolumn{3}{|c|}{ Registered terminal situation } \\
\hline & Yes & No & $P$ & Yes & No & $P$ \\
\hline & $n=104$ & $n=98$ & & $n=104$ & $N=98$ & \\
\hline & n (\%) & n (\%) & & n (\%) & n (\%) & \\
\hline Urinary catheter & $\begin{array}{l}76 \\
(73.1 \%)\end{array}$ & $\begin{array}{l}77 \\
(78.6 \%)\end{array}$ & 0.363 & $\begin{array}{l}69 \\
(67 \%)\end{array}$ & $\begin{array}{l}70 \\
(72.2 \%)\end{array}$ & 0.427 \\
\hline Central venous catheter & $\begin{array}{l}21 \\
(20.2 \%)\end{array}$ & $\begin{array}{l}27 \\
(27 . \% 6)\end{array}$ & 0.219 & $\begin{array}{l}18 \\
(17.5 \%)\end{array}$ & $\begin{array}{l}25 \\
(26 \%)\end{array}$ & 0.142 \\
\hline Peripheral venous catheter & $\begin{array}{l}95 \\
(91.3 \%)\end{array}$ & $\begin{array}{l}87 \\
(88.8 \%)\end{array}$ & 0.541 & $\begin{array}{l}89 \\
(86.4 \%)\end{array}$ & $\begin{array}{l}75 \\
(77.3 \%)\end{array}$ & 0.095 \\
\hline Nasogastric tube & $\begin{array}{l}20 \\
(19.2 \%)\end{array}$ & $\begin{array}{l}26 \\
(26.5 \%)\end{array}$ & 0.216 & $\begin{array}{l}14 \\
(13.6 \%)\end{array}$ & $\begin{array}{l}22 \\
(22.7 \%)\end{array}$ & 0.095 \\
\hline Enteral nutrition & $\begin{array}{l}9 \\
(8.7 \%)\end{array}$ & $\begin{array}{l}13 \\
(13.3 \%)\end{array}$ & 0.293 & $\begin{array}{l}7 \\
(6.8 \%)\end{array}$ & $\begin{array}{l}10 \\
(10.3 \%)\end{array}$ & - \\
\hline Parenteral nutrition & $\begin{array}{l}13 \\
(12.5 \%)\end{array}$ & $\begin{array}{l}17 \\
(17.3 \%)\end{array}$ & 0.333 & $\begin{array}{l}10 \\
(9.7 \%)\end{array}$ & $\begin{array}{l}16 \\
(16.5 \%)\end{array}$ & 0.154 \\
\hline Non-invasive mechanical ventilation & $\begin{array}{l}5 \\
(4.8 \%)\end{array}$ & $\begin{array}{l}16 \\
(16.3 \%)\end{array}$ & - & $\begin{array}{l}3 \\
(2.9 \%)\end{array}$ & $\begin{array}{l}12 \\
(12.4 \%)\end{array}$ & - \\
\hline Invasive mechanical ventilation & $\begin{array}{l}7 \\
(6.7 \%)\end{array}$ & $\begin{array}{l}26 \\
(26.5 \%)\end{array}$ & - & $\begin{array}{l}4 \\
(3.9 \%)\end{array}$ & $\begin{array}{l}8 \\
(8.2 \%)\end{array}$ & - \\
\hline Transfusions & $\begin{array}{l}24 \\
(23.1 \%)\end{array}$ & $\begin{array}{l}29 \\
(29.6 \%)\end{array}$ & 0.293 & $\begin{array}{l}7 \\
(6.8 \%)\end{array}$ & $\begin{array}{l}11 \\
(11.7 \%)\end{array}$ & - \\
\hline Aspirator & $\begin{array}{l}15 \\
(14.4 \%)\end{array}$ & $\begin{array}{l}25 \\
(25.5 \%)\end{array}$ & 0.048 & $\begin{array}{l}10 \\
(9.7 \%)\end{array}$ & $\begin{array}{l}21 \\
(21.6 \%)\end{array}$ & 0.020 \\
\hline Aerosols & $\begin{array}{l}50 \\
(48.1 \%)\end{array}$ & $\begin{array}{l}60 \\
(61.2 \%)\end{array}$ & 0.061 & $\begin{array}{l}38 \\
(36.9 \%)\end{array}$ & $\begin{array}{l}51 \\
(52.6 \%)\end{array}$ & 0.026 \\
\hline Oxygen therapy & $\begin{array}{l}83 \\
(79.8 \%)\end{array}$ & $\begin{array}{l}81 \\
(82.7 \%)\end{array}$ & 0.605 & $\begin{array}{l}68 \\
(66 \%)\end{array}$ & $\begin{array}{l}73 \\
(75.3 \%)\end{array}$ & 0.152 \\
\hline Hydration & $\begin{array}{l}99 \\
(95.2 \%)\end{array}$ & 95 (96.9\%) & 0.722 & $\begin{array}{l}81 \\
(78.6 \%)\end{array}$ & $\begin{array}{l}85 \\
(87.6 \%)\end{array}$ & 0.091 \\
\hline Antibiotics & $\begin{array}{l}66 \\
(63.5 \%)\end{array}$ & $\begin{array}{l}76 \\
(77.6 \%)\end{array}$ & 0.029 & $\begin{array}{l}40 \\
(38.8 \%)\end{array}$ & $\begin{array}{l}58 \\
(59.8 \%)\end{array}$ & 0.003 \\
\hline Drainage & $\begin{array}{l}17 \\
(16.3 \%)\end{array}$ & $\begin{array}{l}13 \\
(13.3 \%)\end{array}$ & 0.538 & $\begin{array}{l}10 \\
(9.7 \%)\end{array}$ & $\begin{array}{l}7 \\
(7.2 \%)\end{array}$ & - \\
\hline Catheterisation & $\begin{array}{l}3 \\
(2.9 \%)\end{array}$ & $\begin{array}{l}7 \\
(7.1 \%)\end{array}$ & - & $\begin{array}{l}1 \\
(1.0 \%)\end{array}$ & $\begin{array}{l}2 \\
(2.1 \%)\end{array}$ & - \\
\hline ICU consult & $\begin{array}{l}21 \\
(20.2 \%)\end{array}$ & $\begin{array}{l}35 \\
(35.7 \%)\end{array}$ & 0.014 & $\begin{array}{l}7 \\
(6.7 \%)\end{array}$ & $\begin{array}{l}10 \\
(10.2 \%)\end{array}$ & - \\
\hline ICU ingress & $\begin{array}{l}12 \\
(11.5 \%)\end{array}$ & $\begin{array}{l}25 \\
(25.5 \%)\end{array}$ & 0.010 & $\begin{array}{l}8 \\
(7.7 \%)\end{array}$ & $\begin{array}{l}23 \\
(23.7 \%)\end{array}$ & 0.002 \\
\hline Dialysis & $\begin{array}{l}5 \\
(4.8 \%)\end{array}$ & $\begin{array}{l}5 \\
(5.1 \%)\end{array}$ & - & $\begin{array}{l}3 \\
(2.9 \%)\end{array}$ & $\begin{array}{l}4 \\
(4.1 \%)\end{array}$ & - \\
\hline Active oncological treatment (in oncology patients $n=81$ ) & $\begin{array}{l}5 \\
(4.8 \%)\end{array}$ & $\begin{array}{l}5 \\
(5.1 \%)\end{array}$ & - & $1(1 \%)$ & $2(2.1 \%)$ & - \\
\hline
\end{tabular}

and modifications in respiratory support and the administration of vasoactive drugs and dialysis.

Palliative sedation was noted in a high percentage of clinical histories compared with the rest of the end-oflife decisions and was also documented at a later time in the patient's illness. This finding coincides with the literature, which indicates that sedation is a frequent measure and is often applied late in the patient's illness $[3,15,40]$. The pressure that family members place on the physician, insistently demanding sedation to alleviate the symptoms and to avoid having to witness their ill family member's suffering, can condition its implementation [41]. In this sense, some studies indicate that the burden of responsibility that family members sometimes 
Table 5 Interventions performed for patients registered as terminal with respect to the registration time point

\begin{tabular}{|c|c|c|c|c|}
\hline \multirow[t]{3}{*}{ Interventions provided in the Final $48 \mathrm{~h}$} & \multicolumn{4}{|c|}{ Registered terminal situation before the final $48 \mathrm{~h}$} \\
\hline & \multicolumn{2}{|c|}{$\begin{array}{l}\text { Yes } \\
n=71\end{array}$} & \multicolumn{2}{|c|}{$\begin{array}{l}\mathrm{No} \\
N=33\end{array}$} \\
\hline & $n$ & $\%$ & $n$ & $\%$ \\
\hline Urinary catheter & 46 & $64.8 \%$ & 23 & $69.7 \%$ \\
\hline Central venous catheter & 11 & $15.5 \%$ & 7 & $21.2 \%$ \\
\hline Peripheral venous catheter & 58 & $81.7 \%$ & 31 & $93.9 \%$ \\
\hline Nasogastric tube & 8 & $11.3 \%$ & 6 & $18.1 \%$ \\
\hline Enteral nutrition & 3 & $4.2 \%$ & 4 & $12.1 \%$ \\
\hline Parenteral nutrition & 6 & $8.4 \%$ & 4 & $12.1 \%$ \\
\hline Non-invasive mechanical ventilation & 1 & $1.4 \%$ & 3 & $9 \%$ \\
\hline Invasive mechanical ventilation & 1 & 1.4 & 2 & $6.1 \%$ \\
\hline Transfusions & 2 & $2.8 \%$ & 5 & $15.1 \%$ \\
\hline Aspirator & 7 & $9.8 \%$ & 3 & $9 \%$ \\
\hline Aerosols & 20 & $28.2 \%$ & 18 & $54.5 \%$ \\
\hline Oxygen therapy & 43 & $60.5 \%$ & 25 & $75.7 \%$ \\
\hline Hydration & 55 & $77.5 \%$ & 26 & $78.8 \%$ \\
\hline Antibiotics & 23 & $32.4 \%$ & 17 & $24 \%$ \\
\hline Drainage & 6 & $8.45 \%$ & 4 & $12.1 \%$ \\
\hline Catheterisation & 0 & $0 \%$ & 1 & $3 \%$ \\
\hline ICU consult & 3 & $4.2 \%$ & 4 & $12.1 \%$ \\
\hline ICU ingress & 3 & $4.2 \%$ & 5 & $15.1 \%$ \\
\hline Dialysis & 2 & $2.8 \%$ & 1 & $3 \%$ \\
\hline Active oncological treatment (in oncology patients $n=81$ ) & 0 & $0 \%$ & 1 & $3 \%$ \\
\hline
\end{tabular}

feel regarding the decision to use palliative sedation generates significant feelings of anxiety [42].

It is important to note that medical end-of-life decisions are registered very late in clinical histories. A great number of decisions were documented with a mean time before death equal to or less than $48 \mathrm{~h}$. Any documentation of medical end-of-life decisions with a mean time before death greater than 14 days was almost non-existent.

However, it is interesting to note the great percentage of end-of-life decisions that were documented in clinical histories that did not include an explicit recognition of the terminal status, which suggests that in many cases, formal recognition of the terminal situation in the clinical history is not necessary to produce certain decisions closely related to the end of life.

Regarding the time point at which the terminal situation is registered, it is notable that with the exception of a higher rate of opioid prescription, no differences were observed in the application of interventions or professionals' decisions in relation to whether the patient's terminal status was registered in the clinical history.

Regarding limitations, the first to note are those inherent in conducting a retrospective study.
Second, regarding this research, terminal illness situation was considered according only the data reported in the clinical histories reviewed. This means that patients or caregivers were not necessarily aware of this situation at the time of data collection.

Third, the included clinical histories were selected based on cause of death, allowing for a certain number of clinical histories that were not reviewed, as they did not indicate the patient's underlying disease as the cause of death.

Finally, it is worth noting that the low frequency of implementation of the decisions and interventions that were registered impeded the use of a parametric analysis, which limited the ability to extrapolate some of the results obtained in this study.

\section{Conclusions}

The results of this research highlight that the care received in hospital environments by patients who are in the terminal phase of their disease is characterized by the continuation of numerous interventions and therapeutic decisions that are typical for acute disease and far from the objectives of palliative care. When there is an explicit reference to the terminal phase of a disease in 
clinical histories, the number of interventions is reduced, and the number of end-of-life-related decisions is increased. However, for many routine interventions, patients continue to be treated like any other patient despite the registration of their terminal situation in the clinical history.

According to these conclusions, it is necessary to undertake without delay educational interventions to improve the training of all professionals of acute care hospitals involved in the care of patients in a terminal illness situation. Secondly, it is also necessary to involve health managers, in the implementation of interventions and procedures to improve management of terminal illness situation in hospital settings, including improving data collected in clinical histories.

\section{Abbreviations}

DNR: Do not resuscitate; ICD-9: International statistical classification of diseases and related health problems (9th version); ICU: Intensive care unit

\section{Acknowledgements}

Not applicable.

\section{Funding}

This work is part of an investigative project financed by the Department of Health of the Board of Andalucía in its 2010 call for papers, titled Variability of Clinical Practice and Conditional Factors in the Implementation of the Processes of Attention at End of Life'.Ref: PI-0670-2010.

\section{Availability of data and materials}

The datasets generated and/or analysed during the current study are not publicly available due individual privacy but are available from the corresponding author on reasonable request.

\section{Authors' contributions}

All authors have made substantial contributions to the manuscript. CCC, RMJ, $\mathrm{CHM}, \mathrm{EHL}, \mathrm{FOV}$ and MPGC have participated in data collection. CCC, RMJ, CHM and MPGC have participated in data analysis. CCC, RMJ and MPGC have written the final manuscript. All authors read and approved the final manuscript.

\section{Competing interests}

The authors declare that they have no competing interests.

\section{Consent for publication}

Not applicable.

\section{Ethics approval and consent to participate}

The study was approved by the ethics committee of Hospital Clínico San Cecilio, Hospital Virgen de las Nieves, Hospital Comarcal de Baza, Hospital Santa Ana de Motril (PI-0670-2010).

\section{Author details}

${ }^{1}$ Foundation of Progress and Health, Andalusian Health Service, Granada, Spain. ${ }^{2}$ Nursing Department, University of Granada, Granada, Spain. ${ }^{3}$ General Hospital of the Virgen de las Nieves of Granada, Andalusian Health Service, Granada, Spain. ${ }^{4}$ Hospital Santa Ana, Andalusian Health Service, Motril, Spain.

Received: 22 December 2015 Accepted: 26 October 2016

\section{Published online: 07 November 2016}

\section{References}

1. Walling AM, Asch SM, Lorenz KA, Roth CP, Barry T, Kahn KL, et al. The quality of care provided to hospitalized patients at the end of life. Arch Intern Med. 2010;170(12):1057-63.

2. Price $\mathrm{S}$, Haxby E. Managing futility in critically ill patients with cardiac disease. Nat Rev Cardiol. 2013;10(12):723-31.
3. Aldasoro E, Pérez A, Olaizola MT. La asistencia a pacientes en la fase final de la vida: revisión sistemática de la literatura y estudio en el medio hospitalario del País Vasco: Gobierno Vasco, Departamento de Sanidad; Vitoria-Gasteiz. 2003.

4. Ellershaw J, Ward C. Care of the dying patient: the last hours or days of life. BMJ. 2003;326(7379):30-4.

5. Navarro Sanz R, Lopez AC. Approximation to palliative care in the advanced non-malignant diseases. An Med Interna. 2008;25(4):187-91.

6. Schneider N, Oster P, Hager K, Klindtworth K. Identifying elderly patients with advanced heart failure at the end of life. Int J Cardiol. 2011;153(1):98-9.

7. Sullivan AM, Lakoma MD, Matsuyama RK, Rosenblatt L, Arnold RM, Block SD. Diagnosing and discussing imminent death in the hospital: a secondary analysis of physician interviews. J Palliat Med. 2007;10(4):882-93.

8. Glare $P$, Sinclair C, Downing M, Stone P, Maltoni M, Vigano A. Predicting survival in patients with advanced disease. Eur J Cancer. 2008;44(8):1146-56.

9. García-Caro M, Cruz-Quintana F, Schmidt Río-Valle J, Muñoz-Vinuesa A, Montoya-Juárez R, Prados-Peña D, et al. Influencia de las emociones en el juicio clínico de los profesionales de la salud a propósito del diagnóstico de enfermedad terminal. Int J Clin Health Psychol. 2010;10(1):57-73.

10. Christakis NA, Lamont EB. Extent and determinants of error in doctors' prognoses in terminally ill patients: prospective cohort study. BMJ. 2000; 320(7233):469-72

11. Gripp S, Moeller S, Bolke E, Schmitt G, Matuschek C, Asgari S, et al. Survival prediction in terminally ill cancer patients by clinical estimates, laboratory tests, and self-rated anxiety and depression. J Clin Oncol. 2007;25(22):3313-20.

12. Toscani F, Di Giulio P, Brunelli C, Miccinesi G, Laquintana D, End-of-Life Observatory Group. How people die in hospital general wards: a descriptive study. J Pain Symptom Manage. 2005;30(1):33-40.

13. Hui D, Con A, Christie G, Hawley PH. Goals of care and end-of-life decision making for hospitalized patients at a canadian tertiary care cancer center. J Pain Symptom Manage. 2009;38(6):871-81.

14. Buiting HM, van Delden JJ, Rietjens JA, Onwuteaka-Philipsen BD, Bilsen J, Fischer $\mathrm{S}$, et al. Forgoing artificial nutrition or hydration in patients nearing death in six European countries. J Pain Symptom Manage. 2007;34(3):305-14.

15. Chambaere K, Bilsen J, Cohen J, Rietjens JA, Onwuteaka-Philipsen BD, Mortier F, et al. Continuous deep sedation until death in Belgium: a nationwide survey. Arch Intern Med. 2010;170(5):490-3.

16. Godfrey G, Hilton A, Bellomo R. To treat or not to treat: withholding treatment in the ICU. Curr Opin Crit Care. 2013;19(6):624-9.

17. Luce JM. End-of-life decision making in the intensive care unit. Am J Respir Crit Care Med. 2010;182(1):6-11.

18. Graw JA, Spies CD, Wernecke KD, Braun JP. Managing end-of-life decision making in intensive care medicine-a perspective from charite hospital, germany. PLoS One. 2012;7(10):e46446.

19. Real de Asua D, Alcala-Zamora J, Reyes A. Evolution of end-of-life practices in a Spanish intensive care unit between 2002 and 2009. J Palliat Med. 2013; 16(9):1102-7.

20. Earle CC, Neville BA, Landrum MB, Souza JM, Weeks JC, Block SD, et al. Evaluating claims-based indicators of the intensity of end-of-life cancer care. Int J Qual Health Care. 2005;17(6):505-9.

21. Barbera $L$, Paszat $L$, Chartier $C$. Indicators of poor quality end-of-life cancer care in Ontario. J Palliat Care. 2006;22(1):12-7.

22. Sato K, Miyashita M, Morita T, Sanjo M, Shima Y, Uchitomi Y. Quality of endof-life treatment for cancer patients in general wards and the palliative care unit at a regional cancer center in Japan: a retrospective chart review. Support Care Cancer. 2008;16(2):113-22.

23. Sykes N. End of life issues. Eur J Cancer. 2008;44(8):1157-62.

24. Campbell ML. Terminal dyspnea and respiratory distress. Crit Care Clin. 2004; 20(3):403-17. viii-ix.

25. Braun UK, Beyth RJ, Ford ME, McCullough LB. Defining limits in care of terminally ill patients. BMJ. 2007;334(7587):239-41.

26. Ministry of Health, Social Services and Equality. Palliative care strategy of the national health system (2010-2014). Madrid: Ministry of Health, Social Services and Equality; 2011.

27. Vila Santasuana A, Celorrio Jimenez N, Sanz Salvador X, Martinez Montauti J, Diez-Cascon Menendez E, Puig RC. The final week of life in an acute care hospital: review of 401 consecutive patients. Rev Esp Geriatr Gerontol. 2008; 43(5):284-90

28. Becker G, Sarhatlic R, Olschewski M, Xander C, Momm F, Blum HE. End-oflife care in hospital: current practice and potentials for improvement. J Pain Symptom Manage. 2007;33(6):711-9. 
29. Earle CC, Landrum MB, Souza JM, Neville BA, Weeks JC, Ayanian JZ. Aggressiveness of cancer care near the end of life: is it a quality-of-care issue? J Clin Oncol. 2008;26(23):3860-6.

30. Aabom B, Kragstrup J, Vondeling H, Bakketeig LS, Stovring H. Defining cancer patients as being in the terminal phase: who receives a formal diagnosis, and what are the effects? J Clin Oncol. 2005:23(30):7411-6.

31. Dalgaard KM, Bergenholtz H, Nielsen ME, Timm H. Early integration of palliative care in hospitals: a systematic review on methods, barriers, and outcome. Palliat Support Care. 2014;13:1-19.

32. Middlewood S, Gardner G, Gardner A. Dying in hospital: medical failure or natural outcome? J Pain Symptom Manage. 2001;22(6):1035-41.

33. Raijmakers NJ, Fradsham S, van Zuylen L, Mayland C, Ellershaw JE, van der Heide $A$, et al. Variation in attitudes towards artificial hydration at the end of life: a systematic literature review. Curr Opin Support Palliat Care. 2011;5(3):265-72.

34. Torres-Vigil I, Mendoza TR, Alonso-Babarro A, De Lima L, Cardenas-Turanzas M, Hernandez M, et al. Practice patterns and perceptions about parenteral hydration in the last weeks of life: a survey of palliative care physicians in Latin America. J Pain Symptom Manage. 2012;43(1):47-58.

35. Good P, Richard R, Syrmis W, Jenkins-Marsh S, Stephens J. Medically assisted hydration for adult palliative care patients. Cochrane Database Syst Rev. 2014;4:CD006273.

36. Raijmakers NJ, van Zuylen L, Costantini M, Caraceni A, Clark J, Lundquist G, et al. Artificial nutrition and hydration in the last week of life in cancer patients. A systematic literature review of practices and effects. Ann Oncol. 2011;22(7):1478-86.

37. Bradley NM, Sinclair E, Danjoux C, Barnes EA, Tsao MN, Farhadian M, et al. The do-not-resuscitate order: incidence of documentation in the medical records of cancer patients referred for palliative radiotherapy. Curr Oncol. 2006;13(2):47-54

38. Levin TT, Li Y, Weiner JS, Lewis F, Bartell A, Piercy J, et al. How do-notresuscitate orders are utilized in cancer patients: timing relative to death and communication-training implications. Palliat Support Care. 2008;6(4):341-8.

39. Carrion Torre M, Zubizarreta Iriarte E, Sarasa Monreal MM, Margall Coscojuela MA, Asiain Erro MC. Effect of the do-not-resuscitate orders on the critical patient care plan. Enferm Intensiva. 2008;19(1):14-22.

40. Crespo M, Cano A, Lledó R, Codina C, Terés J. Sedación terminal en pacientes de un hospital de tercer nivel:frecuencia y factores que inducen su administración. Rev Esp Geriatr Gerontol. 2001;36(4):234-7.

41. Blanker MH, Koerhuis-Roessink M, Swart SJ, Zuurmond WW, van der Heide A, Perez RS, et al. Pressure during decision making of continuous sedation in endof-life situations in Dutch general practice. BMC Fam Pract. 2012;13:68.

42. Bruinsma SM, Rietjens JA, Seymour JE, Anquinet L, van der Heide A. The experiences of relatives with the practice of palliative sedation: a systematic review. J Pain Symptom Manage. 2012;44(3):431-45.

\section{Submit your next manuscript to BioMed Central and we will help you at every step:}

- We accept pre-submission inquiries

- Our selector tool helps you to find the most relevant journal

- We provide round the clock customer support

- Convenient online submission

- Thorough peer review

- Inclusion in PubMed and all major indexing services

- Maximum visibility for your research

Submit your manuscript at www.biomedcentral.com/submit

BioMed Central 